\title{
Perbandingan Fungsi Fagositosis Neutrofil pada Sindrom Nefrotik Resisten Steroid dengan Sindrom Nefrotik Sensitif Steroid
}

\author{
Saiful Mujab, Wistiani \\ Departemen Ilmu Kesehatan Anak Fakultas Kedokteran Universitas Diponegoro/RS Dr. Kariadi, Semarang
}

\begin{abstract}
Latar belakang. Pasien sindrom nefrotik (SN) mempunyai kelainan fungsi sistem kekebalan tubuh karena kurang protein opsonin dan reseptornya. Anak dengan sindrom nefrotik resisten steroid (SNRS) mempunyai prognosis yang lebih buruk dibandingkan dengan sindrom nefrotik sensitif steroid (SNSS). Salah satu gangguan sistem imun yang pernah diteliti antara lain fungsi fagositosis neutrofil, tetapi hasilnya tidak konsisten.

Tujuan. Membandingkan fungsi fagositosis neutrofil pada anak penderita SNRS dengan SNSS.

Metode. Desain cross sectional dengan 2 kelompok, yaitu SNRS dan SNSS. Penelitian dilakukan di RS Dr. Kariadi Semarang pada bulan Mei 2013 dengan pengambilan sampel secara consecutive sampling. Fungsi fagositosis neutrofil diukur dengan metode latex yang dinyatakan sebagai indeks fagositosis. Analisis statistik dikerjakan dengan Mann Whitney test.

Hasil. Didapatkan 18 anak dengan SN yang terdiri atas 10 anak SNSS, serta 8 anak SNRS. Rerata indeks fagositosis neutrofil dari kelompok SNSS lebih rendah daripada anak sehat, tetapi perbedaan ini tidak bermakna secara statistik. Rerata indeks fagositosis neutrofil dari kelompok SNRS bermakna secara statistik lebih rendah daripada anak sehat, tetapi tidak ada perbedaan yang bermakna secara statistik antara kelompok SNRS dibandingkan dengan kelompok SNSS.

Kesimpulan. Tidak ada perbedaan antara fungsi fagositosis neutrofil pada anak penderita SNRS dibandingkan dengan SNSS.
\end{abstract}

Sari Pediatri 2015;17(3):210-5.

Kata kunci: sindrom nefrotik resisten steroid, sindrom nefrotik sensitif steroid, fagositosis neutrofil

\section{Comparasion between Phagocytosis Neutrophil Function in Children Steroid Resistant Nephrotic Syndrome Patients with Steroid Sensitive Nephrotic Syndrome}

Saiful Mujab, Wistiani

Background. Patients with nephrotic syndrome (NS) are known to have the immune system disorders because of lack of opsonin proteins and receptors, increased free radicals exposed the neutrophils and adverse effect of immunosupressive agent, result in increased risk of infection. Children with steroid resistant nephrotic syndrome (SRNS) had more poor prognosis than those of steroid sensitive nephrotic syndrome (SSNS). One of the immune system disorders that has been studied was neutrophils phagocytosis function but the results remain inconsistent.

Objective. To compare the neutrophil phagocytosis function of children with SRNS and SSNS.

Methods. Cross sectional study design, with two groups of subjects: children with SRNS and SSNS, conducted in Dr. Kariadi Hospital in May 2013 by consecutive sampling. The neutrophil phagocytosis function was studied by the method of phagocytosis of latex bead that stated index of phagocyting neutrophils. Statistic analysis were used Mann Whitney test.

Results. We identified 18 children with NS, consisted of 10 children with SSNS and 8 children with SRNS. The mean index of phagocyting neutrophils of SSNS children was lower than healhty children but not statistically significant. The mean index of neutrophil phagocytosis of SRNS children was significanly lower in than those of healhty children, but there was no statistically significant difference in phagocytosis function of neutrophils of them when compared to those of sensitive steroid patients. Conclusion. There were no significant differences of neutrophil phagocytosis function in children with SRNS and SSNS. Sari Pediatri 2015;17(3):210-5.

Keywords: steroid resistant nephrotic syndrome, steroid sensitive nephrotic syndrome, phagocytosis function of neutrophils 


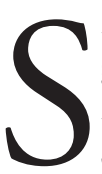
indrom nefrotik merupakan suatu kumpulan gejala klinik yang meliputi adanya proteiuria masif, hipoalbuminemia, edema dan dapat disertai hiperkolesterolemia. ${ }^{1}$ Berdasarkan respon terhadap terapi steroid, SN diklasifikasikan menjadi sindrom sensitif steroid dan sindrom nefrotik resisten steroid. Sindrom nefrotik resisten steroid dikaitkan dengan prognosis yang buruk karena penurunan laju filtrasi glomerulus yang lebih besar dibandingkan dengan anak yang mendapat terapi imunosupresif. ${ }^{2,3}$

Sindrom nefrotik merupakan penyakit ginjal yang umum terjadi pada anak. Insidennya diperkirakan berkisar 2 sampai 7 kasus baru per 100000 anak, dan prevalensinya sekitar 16 kasus per 100.000 anak, atau $1: 6000 .{ }^{4}$ Di Indonesia, insiden diperkirakan 6 kasus per 100.000 anak per tahun. ${ }^{5}$ Pada anak yang lebih muda, kemungkinan terjadinya $\mathrm{SN}$ pada laki-laki dan perempuan adalah 2:1. Perbandingan ini menjadi sama ketika menginjak remaja dan dewasa. Usia puncak dari SN adalah 2 tahun dan 70\%-80\% kasus ini terjadi pada usia di bawah 6 tahun. ${ }^{4}$

Dampak SN terhadap tumbuh kembang anak merupakan akibat dari proses terjadinya penyakit itu sendiri maupun dari efek samping pengobatan dengan kortikosteroid. ${ }^{6}$ Dalam perjalanan penyakitnya, penderita $\mathrm{SN}$ mempunyai risiko untuk terjadinya infeksi. ${ }^{7}$ Kejadian infeksi penderita SN karena adanya kelainan fungsional dalam sistem kekebalan. Kurangnya protein yang mengopsonisasi target, seperti immunoglobin atau protein komplemen dan kurangnya reseptor untuk mengikat target yang teropsonisasi adalah kelainan fungsional dalam sistem kekebalan. ${ }^{8}$ Di samping itu, kelainan fungsional lainnya adalah peningkatan oxidative stress yang menimpa sel monosit $^{9}$ dan polimorfonuklear $(\mathrm{PMN})^{10}$ sehingga mengganggu fungsi sel tersebut, salah satunya adalah fagositosis.

Penelitian Yetgin $\mathrm{dkk}^{11}$ menemukan adanya defek kapasitas bakterisidal sel PMN pada penderita SN. Waga $\mathrm{dkk}^{12}$ telah membuktikan adanya penurunan fungsi fagositosis monosit pada penderita $\mathrm{SN}$ resisten steroid. Branellec $\mathrm{dkk}^{13}$ juga menyimpulkan adanya penurunan fungsi fagositosis monosit pada penderita sindrom nefrotik.

Penelitian Estevez $\mathrm{dkk}^{14}$ pada 23 anak dengan minimal change nephrotic syndrome (MCNS) relaps tanpa terapi dan 26 anak normal sebagai kontrol tidak menemukan gangguan fungsi fagositosis sel PMN maupun monosit. Hal serupa juga dibuktikan oleh Akyol dkk ${ }^{10}$ pada 30 orang dewasa dengan SN baru tanpa terapi, dan 32 orang dewasa sehat sebagai kelompok kontrol tidak menemukan adanya perbedaan yang signifikan dari fungsi fagositosis PMN dan monosit.

\section{Metode}

Penelitian cross sectional dilakukan di Poliklinik dan Bangsal Anak Rumah Sakit Dokter Kariadi Semarang periode Mei 2013 dengan pengambilan sampel secara consecutive sampling. Kelompok kasus adalah anak SNRS yang memenuhi kriteria inklusi, yaitu anak dengan jumlah leukosit normal dan bersedia mengikuti penelitian. Kriteria eksklusi adalah menderita penyakit sickel cell, Diabetes Mellitus, penyakit ginjal kronik, dan malnutrisi.

Cara sampling dilakukan dengan consecutive sampling. Besar sampel untuk penelitian ini dihitung dengan menggunakan rumus besar sampel untuk analitik numerik tidak berpasangan, didapatkan besar sampel 18 anak. Pemeriksaan fagositosis neutrofil dikerjakan dengan metode latex, dinyatakan dengan indeks fagositosis.

Uji Mann Whitney test digunakan untuk menganalisis perbedaan indeks fagositosis neutrofil pada anak penderita SN dibandingkan dengan anak sehat, dan perbedaan indeks fagositosis neutrofil pada anak SNRS dibandingkan dengan anak SNSS. Nilai p dianggap bermakna apabila $\mathrm{p}<0,05$. Analisis data menggunakan program komputer.

\section{Hasil}

Selama kurang lebih 1 tahun periode penelitian telah diikutsertakan 18 anak dengan SN dan 18 anak sehat yang memenuhi kriteria inklusi. Didapatkan 28 anak laki-laki dan 8 perempuan yang terdiri atas 14 laki-laki dan 4 perempuan dengan SN serta 14 laki-laki dan 4 perempuan sehat. Subjek penelitian juga dikelompokkan ke dalam rentang usia, tidak didapatkan anak dengan SN maupun anak sehat dengan rentang usia 0-<2 tahun, usia 2-6 tahun 7 anak dengan SN dan 5 anak sehat, serta usia $>6$ tahun 11 anak dengan SN dan 13 anak sehat (Tabel 1).

Dari 18 anak SN, terdapat 7 laki-laki dan 3 perempuan dengan SNSS serta 7 laki-laki dan 1 (5,57\%) perempuan dengan SNRS (Tabel 2). 
Rerata indeks fagositosis neutrofil pada anak SNSS $(72,65 \pm 88,027)$ lebih rendah dibandingkan dengan anak sehat $(74,03 \pm 29,825)$ tetapi secara statistik perbedaan ini tidak bermakna $(\mathrm{p}=0,195)$ (Gambar 1).

Rerata indeks fagositosis neutrofil pada anak SNRS $(42,76 \pm 53,87)$ lebih rendah dibandingkan dengan anak sehat $(74,03 \pm 29,82)$ dan secara statistik perbedaan ini bermakna $(\mathrm{p}=0,040)$ (Gambar 2).

Tidak ada perbedaan yang bermakna secara statistik

Tabel 1. Karakteristik subjek penelitian

\begin{tabular}{lccc}
\hline \multirow{2}{*}{ Variabel } & \multicolumn{3}{c}{ Diagnosis } \\
\cline { 2 - 4 } & $\mathrm{SN}$ & Anak sehat & Total \\
\cline { 2 - 4 } & $\mathrm{n}$ & $\mathrm{n}$ & $\mathrm{n}$ \\
\hline Jenis kelamin & & & \\
Laki-laki & 14 & 14 & 28 \\
$\quad$ Perempuan & 4 & 4 & 8 \\
Umur (tahun) & & & \\
$0-<2$ & 0 & 0 & 0 \\
$2-6$ & 7 & 5 & 12 \\
$>6$ & 11 & 13 & 24 \\
\hline
\end{tabular}

Tabel 2. Karakteristik berdasarkan respon terhadap terapi steroid

\begin{tabular}{lccc}
\hline & \multicolumn{3}{c}{ Diagnosis } \\
\cline { 2 - 4 } Jenis kelamin & SNSS & SNRS & Total \\
\cline { 2 - 4 } & $\mathrm{n}$ & $\mathrm{n}$ & $\mathrm{n}$ \\
\hline Laki-laki & 7 & 7 & 14 \\
Perempuan & 3 & 1 & 4 \\
\hline
\end{tabular}

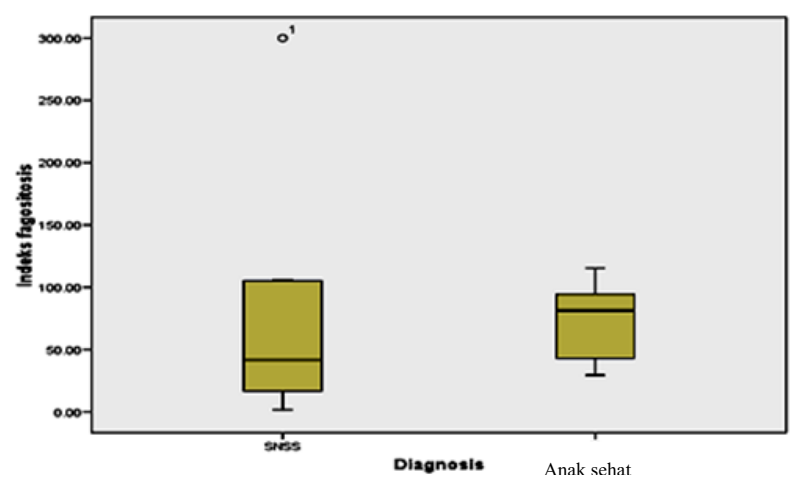

Gambar 1. Grafik perbedaan rerata indeks fagositosis neutrofil anak penderita sindrom nefrotik sensitif steroid dibandingkan dengan anak sehat antara kelompok pasien SNRS $(42,76 \pm 53,871)$ dibandingkan dengan pasien SNSS $(72,65 \pm 88,027)$ $(\mathrm{p}=0,266)($ Gambar 3).

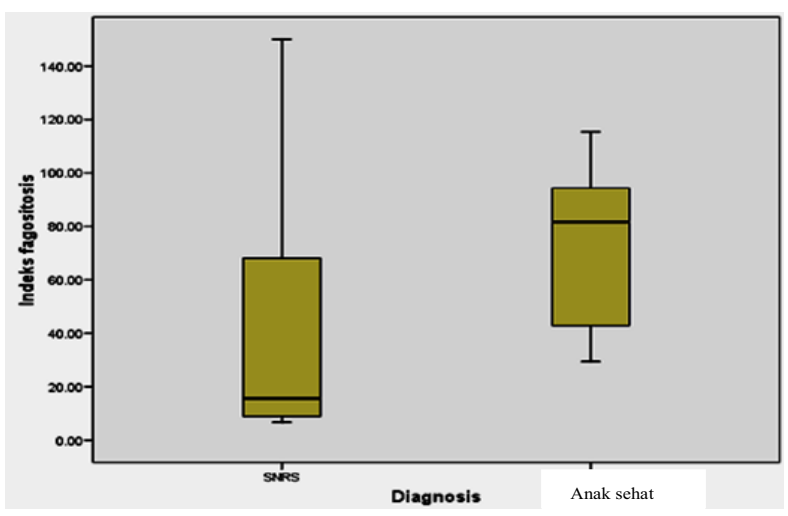

Gambar 2. Grafik perbedaan rerata indeks fagositosis neutrofil anak penderita sindrom nefrotik resisten steroid dibandingkan dengan anak sehat

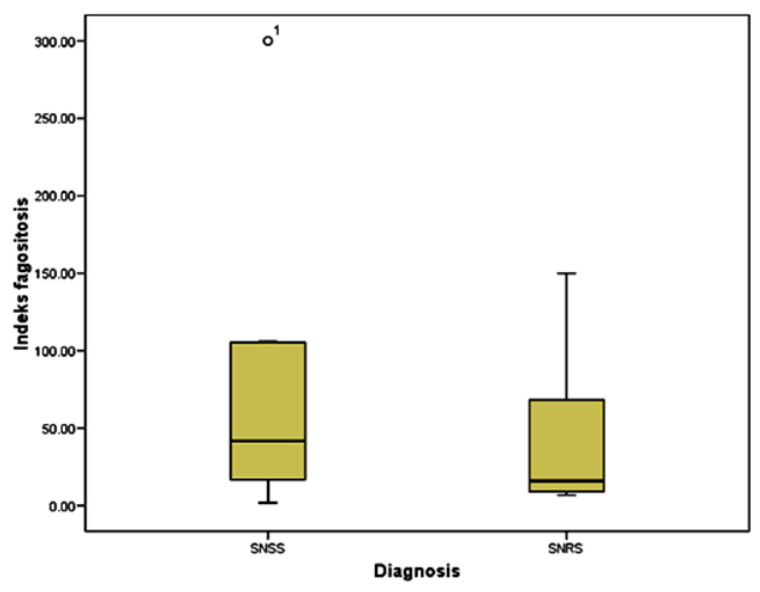

Gambar 3. Grafik perbedaan rerata indeks fagositosis neutrofil anak penderita sindrom nefrotik resisten steroid dibandingkan dengan anak penderita sindrom nefrotik sensitif steroid

\section{Pembahasan}

Kasus SN paling banyak ditemukan pada rentang usia $>6$ tahun. Hasil tersebut tidak sesuai dengan pustaka yang ada yang menyebutkan bahwa 70\%- 
$80 \%$ kasus ini terjadi pada usia di bawah 6 tahun. $\mathrm{Hal}$ ini dikarenakan besar sampel yang kecil. Dari penelitian didapatkan jumlah penderita laki-laki lebih banyak daripada perempuan (3,5:1). Hasil tersebut sesuai dengan teori yang ada yang menyebutkan bahwa kemungkinan terjadinya SN pada laki-laki dan perempuan adalah $2: 1 .^{4}$

Rerata indeks fagositosis neutrofil anak SNSS lebih rendah dibandingkan dengan anak sehat, tetapi secara statistik perbedaan ini tidak bermakna. Sementara rerata indeks fagositosis neutrofil anak SNRS lebih rendah dibandingkan dengan anak sehat dan perbedaan ini bermakna secara statistik. Penelitian serupa pernah dilakukan oleh Estevez $\mathrm{dkk}^{14}$ maupun Akyol $\mathrm{dkk}^{10}$ yang tidak menemukan gangguan fungsi fagositosis sel PMN pada SN. Perbedaan tersebut mungkin disebabkan oleh perbedaan subjek. Pada penelitian Estevez $\mathrm{dkk}^{14}$ menggunakan subjek pasien $\mathrm{SN}$ relaps saja, sedangkan Akyol dkk menggunakan sampel pasien SN dewasa. Sindrom nefrotik pada orang dewasa lebih banyak menunjukkan kelainan non-minimal, sedangkan pada anak sebagian besar memperlihatkan kelainan MCNS. Dua bentuk SN, yaitu MCNS dan focal segmental glomerulo sclerosis (FSGS), secara signifikan terjadi defisiensi imunoglobulin dan protein komplemen. ${ }^{12}$ Imunoglobulin IgG dan IgM berfungsi sebagai opsonin dan bekerja bersama sel fagosit untuk meningkatkan proses menelan dan membunuh. IgG dan IgM juga mengaktivasi urutan komplemen sehingga mengakibatkan lisisnya bakteri (jika Gram negatif). ${ }^{15}$

Gangguan fungsi leukosit sebagai akibat dari depresi fungsi limfosit atau defek fagositosis oleh leukosit polimorfonuklear (PMNL) menyebabkan pasien SN rentan terhadap infeksi. ${ }^{16}$ Pemakaian glukokortikosteroid jangka panjang mengakibatkan pasien rentan terhadap infeksi. ${ }^{17}$ Sebuah meta analisis menyimpulkan bahwa durasi penggunaan prednison yang lebih lama dalam episode pertama pada pasien $\mathrm{SN}$ (dosis penuh selama 4 minggu diikuti dosis alternating selama 2-6 bulan) secara signifikan telah mengurangi risiko relaps pada 12-24 bulan tanpa peningkatan kejadian efek samping. Efek samping yang dimaksud meliputi retardasi pertumbuhan, hipertensi, katarak, glaukoma, gangguan psikologis, infeksi, trombosis, dan osteoporosis. ${ }^{18}$

Deplesi imunoglobulin menyebabkan remisi proteinuria pada pasien dengan SNRS transien yang berkembang menjadi stadium akhir gagal ginjal dan kekambuhan proteinuria dini setelah transplantasi ginjal. ${ }^{19}$ Deplesi kadar imunoglobulin disebabkan karena imunoglobulin hilang melalui urin, tanpa kompensasi meningkatnya sintesis. Pada kasus SN juga terjadi penurunan kadar faktor B (C3 proactivator) dan $\mathrm{D}$ (komponen jalur komplemen alternatif) sehingga kemampuan opsonisasi bakteri berkurang. ${ }^{9}$

Penyebab anak SN rentan terhadap infeksi adalah adanya defisiensi imunoglobulin dan protein komplemen, peningkatan oxidative stress yang menimpa sel monosit ${ }^{9}$ dan PMN, ${ }^{10}$ depresi fungsi limfosit atau defek fagositosis oleh leukosit polimorfonuklear. ${ }^{16}$ Neutrofil polimorfonuklear dan monosit memainkan peran penting dalam memerangi infeksi, fungsi utama sel-sel ini adalah fagositosis. ${ }^{20}$ Sebagai bagian dari sistem imun nonspesifik, sel-sel ini memerlukan waktu yang tidak lama (dalam hitungan jam) dalam merespon adanya infeksi dibandingkan sistem imun spesifik. ${ }^{21}$

Dari penelitian didapatkan bahwa rerata indeks fagositosis neutrofil pada anak SNRS lebih rendah dibandingkan dengan anak SNSS, tetapi perbedaan ini secara statistik tidak bermakna. Penelitian Waga $\mathrm{dkk}^{12}$ melaporkan bahwa level fagositosis monosit pada pasien SNRS secara signifikan cenderung rendah. Penurunan fungsi fagositosis mungkin diakibatkan permukaan sel monosit tertutup oleh imun kompleks dan perubahan proliferatif ginjal, sebagian besar kasus SNRS menunjukkan kelainan membranoproliferative glomerulonephritis (MPGN). ${ }^{9}$ Ada korelasi yang kuat antara sensitivitas steroid dan MCNS. Kebanyakan pasien dengan MCNS 90\%-95\% akan berespon terhadap terapi kortikosteroid. Sindrom nefrotik sensitif steroid memiliki hasil yang lebih baik dengan probabilitas tinggi, remisi jangka panjang, dan fungsi ginjal terpelihara. ${ }^{22}$ International Study for Kidney Diseases in Children (ISKDC) juga melaporkan bahwa 93\% dari anak dengan SNSS menunjukkan gambaran MCNS pada biopsinya. Sebagian besar pasien yang tidak mencapai remisi dengan steroid memiliki hasil biopsi ginjal selain MCNS. Diagnosis paling umum pada pasien tersebut adalah FSGS.7

Pada penelitian kami terdapat beberapa keterbatasan antara lain jumlah subjek yang kurang karena keterbatasan waktu dan tidak dilakukannya biopsi untuk mengetahui diagnosis morfologi dari pasien SN. 
Meskipun secara statistik fungsi fagositosis neutrofil pada anak kasus SNRS lebih rendah dibandingkan dengan anak sehat, tidak ada perbedaan bermakna antara fungsi fagositosis neutrofil anak SNRS dibandingkan SNSS. Perlu dilakukan penelitian lebih lanjut dengan disain penelitian kohort dan jumlah subjek yang lebih banyak untuk menilai perbedaan fungsi fagositosis neutrofil anak SNRS dibandingkan dengan SNSS, serta antara anak SNRS early steroid resistance dibandingkan dengan SNRS late steroid resistance.

\section{Daftar pustaka}

1. Alatas H, Tambunan T, Trihono PP, Pardede SO, penyunting. Konsensus tata laksana sindrom nefrotik idiopatik pada anak. Jakarta: UKK Nefrologi IDAI;2005.h.118.

2. Gordillo R, Spitzer A. The nephrotic syndrome. Pediatr Rev 2009;30;94-105.

3. Prikhodina L, Dlin V, Turpitko O, Ignatova M. Immunosupressive treatment and long-term outcome of idiopathic steroid-resistant nephrotic syndrome in children: a 10 year single centre experience. Presented at the World Congress of Nephrology Annual Meeting, Milan, Italy, May 22-26, 2009.

4. Valentini RP, Smoyer WE. Nephrotic syndrome. Dalam: Kher KK, Schnaper HW, Makker SP. Clinical Pediatric Nephrology. Edisi ke-2. London: Informa UK Ltd; 2007.h.155-94.

5. Kosnadi L. Sindrom nefrotik responsif steroid. Dalam: Kosnadi L, Setiati TE, Widjajat R, penyunting. Penyakit ginjal anak. Semarang: Badan Penerbit UNDIP; 2007.h.105-24.

6. Neuhaus TJ, Langlois V, Licht C. Behavioural abnormalities in children with nephrotic syndrome, underappreciated complication of a standart treatment? [Online] Jun 23, 2010 [cited 2012 February 2]. Didapat dari: http://ndt.oxfordjournals.org/content/25/8/2397.full

7. Lane JC, Langman CB, Finberg L, Spitzer A. Pediatric nephrotic syndrome. [Online] Nov 11, 2011 [cited 2012 February 2]. Didapat dari: http://emedicine.medscape.com/ article/982920-overview

8. Laurence A, Chowdary P, Ancliff P. Disorders of granulopoiesis and granulocyte function. Dalam: Arceci RJ, Hann IM, Smith OP, penyunting. Pediatric Hematology. Edisi ke-3. London : Blackwell Publishing Ltd; 2006.h.305-19.
9. Tanaka H, Waga S,Sugimoto K, Kakizaki Yokoyama M. Capacity of $\mathrm{H} 2 \mathrm{O} 2$ release from monocytes in steroidsensitive nephrotic syndrome. Tohoku J Exp Med 1996;178:271-7.

10. Akyol T, Bulucu F, Sener O, Yamanel L, Aydin A, Inal V, dkk. Functions and oxidative stress status of leukocytes in patients with nephrotic syndrome. Biological Trace Element Research 2007;116:237-48.

11. Yetgin S, Gur A, Saatci U. Non-specific immunity in nephrotic syndrome. Acta Paediatr Scand 1980; 69:21-4.

12. Waga S, Takahashi Y, Fujita M, Nagata K, Kuronuma T, Aoyam R. Monocyte function in idiopathic nephrotic syndrome in childhood. Tohoku J exp Med 1983;141:295-303.

13. Branellec A, Laurent J, Heslan JM, Bruneau C, Lagrue G. A transient monocyte defective function in idiopathic nephrotic syndrome. Int Urol Nephrol 1988;20:421-8.

14. Estevez ME, Voyer LE, Craviotto RJ, Ballart IJ, Goicoa MA, Palacios F, dkk. Dysfunction of the monocytemacrophage system in the idiopathic minimal change nephrotic syndrome. Acta Paediatr Scand 1989;78:8793.

15. Hirsch, D, Zee C, penyunting. Veterinary microbiology. Oxford: Blackwell Science; 1999.

16. Boxer LA. Neutrophil disorders: qualitative abnormalities of the neutrophil. Dalam: Beutler E, Lichtman M, Coller BS, Kipps TJ, Seligsohn U, penyunting. Williams Hematology. Edisi ke-6. New York: Mc Graw-hill;2001. h.638.

17. VanBoxtel CJ. Hormones and hormone antagonists. Dalam: VanBoxtel CJ, Santoso B, Edwards IR, penyunting. Drug benefits and risks. International Textbook of Clinical Pharmacology. Amsterdam (Netherlands): IOS Press;2008.h.389-91.

18. Hodson EM, Knight JF, Willis NS, Craig JC. Corticosteroid therapy in nephrotic syndrome: a metaanalysis of randomised controlled trials. Arch Dis Child 2000;83:45-51.

19. Kaneko K. Pathogenesis in childhood idiopathic nephrotic syndrome: an update of patchwork. Curr Pediatric Rev 2009;5:56-64.

20. Brady HJ. Hematopoiesis: an introduction. Dalam: Arceci RJ, Hann IM, Smith OP. Pediatric Hematology. Edisi ke-3. London: Blackwell Publishing Ltd;2006.h.6-7.

21. McDonagh KT, Nienhuis AW. The thalassemias. Dalam: Nathan DG, Oski FA, penyunting. Hematology of 
Saiful Mujab dkk: Perbandingan fungsi fagositosis neutrofil pada SNRS dengan SNSS

infancy and childhood. Edisi ke-4. Philadelphia: WB Saunders Company; 1993.h.832-56.
22. Abeyagunawardena AS. Treatment of steroid sensitive nephrotic syndrome. Indian J Pediatr 2005;72:763-9. 